\title{
GORRESPONDENCE
}

The Editor,

\section{Journal of Glaciology}

SIR,

Secondary polygons in Iceland

In his letter, R. W. Groves (1968) mentions secondary polygons within primary ones, discovered by him on a summit plateau of a $998 \mathrm{~m}$ high peak in north-west Iceland. As $\mathrm{Mr}$ Groves thinks that this species of patterned ground is "possibly hitherto undescribed", I wish to point out that I have already described this type of polygon (Thorarinsson, 1953). I observed these polygons in Berufjördur, east Iceland, about $20 \mathrm{~m}$ above sea-level, and I later observed the same type of polygon in several other places in Iceland, both in lowland and highland areas.

\author{
Division of Earth Sciences, \\ Science Institute, \\ University of Iceland, \\ Reykjavik, Iceland \\ 18 December 1968
}

Sigurdur Thorarinsson

\section{REFERENCES}

Groves, R. W. 1968. Primary and secondary polygons. Journal of Glaciology, Vol. 7, No. 49, p. 1 30-32. [Letter.] Thorarinsson, S. 1953. Anchored stone polygons at low levels within the Iceland basalt regions. Fökull, Ár 3 , p. $37-38$.

SIR, Calving from floating glaciers: comments on $\mathrm{Dr} \mathcal{N}$. Reeh's paper

Reeh's treatment of glacier calving (Reeh, I968) invites some comment. He chooses for corroboration of his theory in the first place the Rink Gletscher, but seems to be unaware that the catastrophic calvings of this glacier have been described in detail, photographed and even filmed (Sorge, 1933[a], [b]). Jakobshavn Isbræ might also occasionally calve like Rink Gletscher; this is a possible explanation of the big waves which sometimes enter the harbour of Jakobshavn. But nobody has to my knowledge yet seen one of its big calvings, and this glacier cannot safely be adduced (Reeh, I968, p. 23I) as a support of the author's theory. It might also be pointed out that the manner of calving of the Rink Gletscher, a big detachment at roughly fortnightly intervals, is not typical for the fast-moving ice streams of Greenland which generally shed their ice surplus day by day through the formation of individual icebergs in a manner not covered by the theory.

Apart from the fact that Rink Gletscher is in a special position, the question arises whether it represents a "floating glacier" at all. The depth of the fjord into which Rink Gletscher calves, diminishes from I $100 \mathrm{~m}$ at $\mathrm{I} 2 \mathrm{~km}$ to $850 \mathrm{~m}$ at $3 \mathrm{~km}$ and $650 \mathrm{~m}$ at $500 \mathrm{~m}$ from the calving front (Sorge, I933[b]). If the fjord retains the same depth, the thickness of the floating glacier cannot exceed $740 \mathrm{~m}$ of which $90 \mathrm{~m}$ can be above sea-level. According to Reeh's figs. 12 and 13 this height is already approached at $1 \mathrm{~km}$ or less from the front. The longitudinal section (fig. 14) deviates about $30^{\circ}$ from the axis of the glacier; in the direction of the flow lines (Carbonnell and Bauer, I968) the near-horizontal part would be considerably shorter. (In a publication received after the first submission of this Correspondence it is flatly stated (Carbonnell and Bauer, 1968) that "le front [of Rinks Isbræ] ne flotte pas". The same is claimed about Jakobshavn Isbræ (Bauer and others, 1968; Carbonnell and Bauer, 1968) which one might rather expect to float in view of the very small inclination of only $24^{\prime}$ of its lowest part.) It would have been interesting if the author had tried to apply his theory to the undoubtedly floating glacier tongues of north Greenland (Koch, 1928).

The theory demands that the front should bend downward before calving. This is true in some cases whilst in others the outermost part of a floating ice shelf is raised (Swithinbank, 1957). A picture of a detaching part of the front of Jakobshavn Isbræ which seems partly higher and partly lower than the intact part, is shown by Bauer and others ( 1968 , fig. 24). It might in this connection be pointed out that, contrary to a perhaps naive expectation of what a forward bending frontal part would do, at both observed big calvings of Rink Gletscher the detached part of the front of about $500 \mathrm{Gg}$ tilted backward (Sorge, 1933[b]). The other big calving that has been described (Drygalski, I897, Bd. I, p. 392) also 